\title{
A circulating anticoagulant occurring after temporal arteritis and controlled by corticosteroid therapy
}

\author{
A. G. W. Whitfield, M. J. MEYNELL, B. M. FESSEY, \\ AND W. A. HUDSON \\ From the United Birmingham Hospitals
}

SYNOPSIS A case is described in which a circulating anticoagulant, inhibiting antihaemophilic globulin, developed following temporal arteritis. The circulating anticoagulant disappeared with steroid therapy, reappearing when steroids were withdrawn. Permanent maintenance therapy appears necessary in this case to prevent haemorrhagic manifestations.

Five types of circulating anticoagulant have been described. The least common are heparin and heparin-like substances (Bell, 1951; Speer, Hill, Maloney, and Roberts, 1955; Quick and Hussey, 1957; Cetengil, Ulutin, and Karaca, 1959). Such anticoagulants are readily identified by the fact that they are neutralized in vitro by protamine sulphate or toluidine blue. A more frequently encountered type is that which occurs in association with systemic lupus erythematosus (Conley and Hartmann, 1952; Bonnin, Cohen, and Hicks, 1956; Medal and Lisker, 1959). It is present in 10 (Frick, 1955) to $16 \%$ (Lee, Sanders, and Kahny, 1955) of patients with systemic lupus and is usually associated with false positive reactions for syphilis and a positive cephalin flocculation test. It appears to retard the conversion of prothrombin to thrombin and does not often produce an overt haemorrhagic tendency. A third type, interfering with thrombin generation, has been observed in association with cryoglobulins, macroglobulins, and other abnormalities of the plasma proteins in such conditions as bacterial endocarditis (Mueller, Ratnoff, and Heinle, 1951) and myelomatosis (André, Dreyfus, Jacob, and Ley, 1952; Eernard, Inceman, Zara, and Christol, 1952). A fourth type is the Bridge anticoagulant present from birth in haemophilia and Christmas disease in addition to the deficiency of antihaemophilic globulin or plasma thromboplastin component (Nour-Eldin and Wilkinson, 1958a and b). It interferes with the formation of thromboplastin and with its action on prothrombin conversion. The fifth and commonest variety of circulating anticoagulant delays clotting at the first phase, preventing thrombo-

Received for publication 13 January 1962 plastin formation by inhibiting antihaemophilic globulin or plasma thromboplastin component. Over 60 examples of this type of case have been reported in the literature. One third of them have been patierits suffering from haemophilia or Christmas disease who have received multiple blood transfusions or injections of antihaemophilic globulin (Munro, 1946; Munro and Munro, 1946; Lamy, Burstein, and Soulier, 1946; Craddock and Lawrence, 1947; Soulier and Burstein, 1948; Conley, Rathbun, Morse, and Robinson, 1948; Tzanck, Soulier, and Blatrix, 1949; Van Creveld, Hoorweg, and Paulssen, 1951, 1953; Verstraete and Vandenbroucke, 1956). One quarter have developed a circulating anticoagulant within a year of parturition (Fantl and Nance, 1946; Conley, Ratnoff, Ellicott, and Hartmann, 1950; O'Brien, 1953; Frick, 1953), and some of these have persisted for many years. In one instance (Frick, 1953) the newborn child had the same circulating anticoagulant as the mother for the first 10 weeks of life but it caused no symptoms. In the remainder of the fifth group the circulating anticoagulant was found in otherwise healthy adults, usually of mature years (Pons and de Torregrosa, 1952; Hougie, 1953; Verstraete and Vandenbroucke, 1956) or in association with a variety of conditions such as tuberculous lymphadenopathy (Lozner, Jolliffe, and Taylor, 1940), reactive lymph node hyperplasia (Conley et al., 1948), chronic nephritis and syphilis (Conley et al., 1948), pemphigus (Quick and Stefanini, 1948; Dieter, Spooner, and Pohle, 1949), dermatitis herpetiformis (Tzanck et al., 1949), myocardial infarction (Singer, Mond, Hyman, and Levy, 1950), rheumatoid arthritis (Collins and Ferriman, 1952), rheumatic heart disease (Hardisty, 1954), tonsillitis 
(Nussey and Dawson, 1957), and ankylosing spondylitis (Douglas, 1958).

This communication reports the development of a circulating anticoagulant of this type following temporal arteritis and of its control with steroid therapy.

\section{CASE REPORT}

A retired farmer, aged 68, was admitted as an emergency to the Queen Elizabeth Hospital, Birmingham, on 29 July 1957 because of a fainting attack which had occurred that morning. A war wound in 1915 had caused a traumatic cataract in the right eye but otherwise he had had no illness of any sort until February 1957 when over a period of a week he had recurrent episodes of transitory loss of vision in the left eye. Each lasted about a minute and about 15 such episodes occurred each day. In April 1957 he began to feel weak and lethargic and developed very severe occipital and left temporal head pains which prevented sleep. The latter symptom persisted for two months and his wife remarked on the prominence of the 'veins' on the left side of his head and face. A blood count at this time showed anaemia and he was given vitamin $B_{12}$, iron, and folic acid without benefit. On admission he was afebrile and there were no objective abnormalities apart from pallor, lethargy, and the rightsided cataract. There was no scalp tenderness and the temporal and occipital arteries were normally pulsatile. The sedimentation rate was $120 \mathrm{~mm}$. in the first hour (Westergren) and the blood count showed 3.37 million red cells per c.mm., haemoglobin $63 \%$, and 10,000 white cells per c.mm. of which $80 \%$ were polymorphs. Skull and chest radiographs were normal and the electrocardiogram was physiological. The urine was normal and the blood urea was $50 \mathrm{mg}$. \%. Occult blood was not found in the stools. A diagnosis of temporal arteritis was made and he was treated with prednisone initially in a dose of $30 \mathrm{mg}$. daily and thereafter gradually reduced to a maintenance level of $15 \mathrm{mg}$. daily. Because of the patient's monocular vision it was decided to con- tinue steroids as long as there was any evidence activity of the disease.

However, though the blood count improved (4.5 millio red cells and $88 \%$ haemoglobin in February 1958) an 8 the patient felt well, the sedimentation rate remaines raised. Eventually, despite the raised sedimentation rate steroids were withdrawn in November 1959. Four monthf later severe spontaneous bruising and ecchymose began and when next seen in August 1960 he had had six such episodes. There were no objective abnormalities on physical examination and the blood count showe $\vec{\Phi}$ $4 \cdot 27$ million red cells, haemoglobin $79 \%, 6,600$ whit cells, a normal differential count, and 208,000 platelet 50 The clotting time was 20 minutes at $37^{\circ} \mathrm{C}$. (Lee and White), the bleeding time was 4 minutes, Hess's test was negative, the prothrombin time was 16.5 seconds (contröt $12 \cdot 5$ seconds) and clot retraction was normal. The plasma fibrinogen was $0.4 \mathrm{~g} . \%$, the blood urea $30 \mathrm{mg} . \%$, and the liver function tests and serum protein electrophoresis were normal. A chest radiograph showed no abnormalityo The thromboplastin generation test showed the presence of a circulating anticoagulant in the patient's plasma (Table I), and using the method of Biggs and Bidwe (1959) this was shown to be an antihaemophilic globulin. inhibitor (Table II).

The patient was readmitted to hospital as an emergency on 19 September 1960 (Fig. 1). There was severe bruising around the right elbow and in the left thigh and a verg large haematoma in the right iliopsoas region preventing extension of the right hip. The clotting time was $2 \mathrm{~d}$ minutes (Lee and White) at $37^{\circ} \mathrm{C}$., haemoglobin $42 \%$ and the platelets 358,000 . He was transfused with 4 pint 8 of blood and given $80 \mathrm{mg}$. of prednisone daily. Ther $\overrightarrow{5}$ were no further haemorrhagic episodes and in 10 days the clotting time had fallen to 9 minutes. After a furthep two weeks it was $7 \frac{1}{2}$ minutes and the thromboplastio generation test was normal. Over the six weeks the prednisone was withdrawn and the patient remained wet with a normal clotting time and thromboplastin generation test but the sedimentation rate was still high $(36 \mathrm{~mm}$. ap. one hour, Westergren). Though there were no furtheg haemorrhagic incidents, two months later the clotting

TABLE I

THROMBOPLASTIN GENERATION TEST USING NORMAL PLATELETS

Normal serum and normal plasma Patient's serum and patient's plasma Normal serum and patient's plasma Patient's serum and normal plasma

$\begin{array}{lllll}14 & 11 & 12 & 15 & 13 \\ 55 & 45 & 28 & 27 & 28 \\ 41 & 22 & 35 & 30 & 27 \\ 13 & 13 & 13 & 14 & 12\end{array}$

TABLE II

DEMONSTRATION OF AN ANTIHAEMOPHILIC GLOBULIN INHIBITOR ${ }^{1}$ (BIGGS AND BIDWELL, 1959)

Normal serum and normal plasma

Normal serum and patient's plasma

Normal serum and normal plasma with an equal volume of patient's plasma

Normal serum and normal plasma with an equal volume of haemophilic plasma

Normal serum and normal plasma with third vol. of patient's plasma

$\begin{array}{lll}25 & 18 & 14 \\ 80 & 78 & 55 \\ 30 & 28 & 20 \\ 35 & 23 & 16 \\ 22 & 16 & 12\end{array}$

${ }^{1}$ The residual antihaemophilic globulin, assayed after incubation for one hour of patient's aluminium hydroxide-treated plasma and porcin $\bar{\gamma}$ antihaemophilic globulin, was $1 \%$ of the residual antihaemophilic globulin assayed after incubation for one hour of a haemophilio aluminium hydroxide-treated plasma and the same amount of porcine antihaemophilic globulin. 


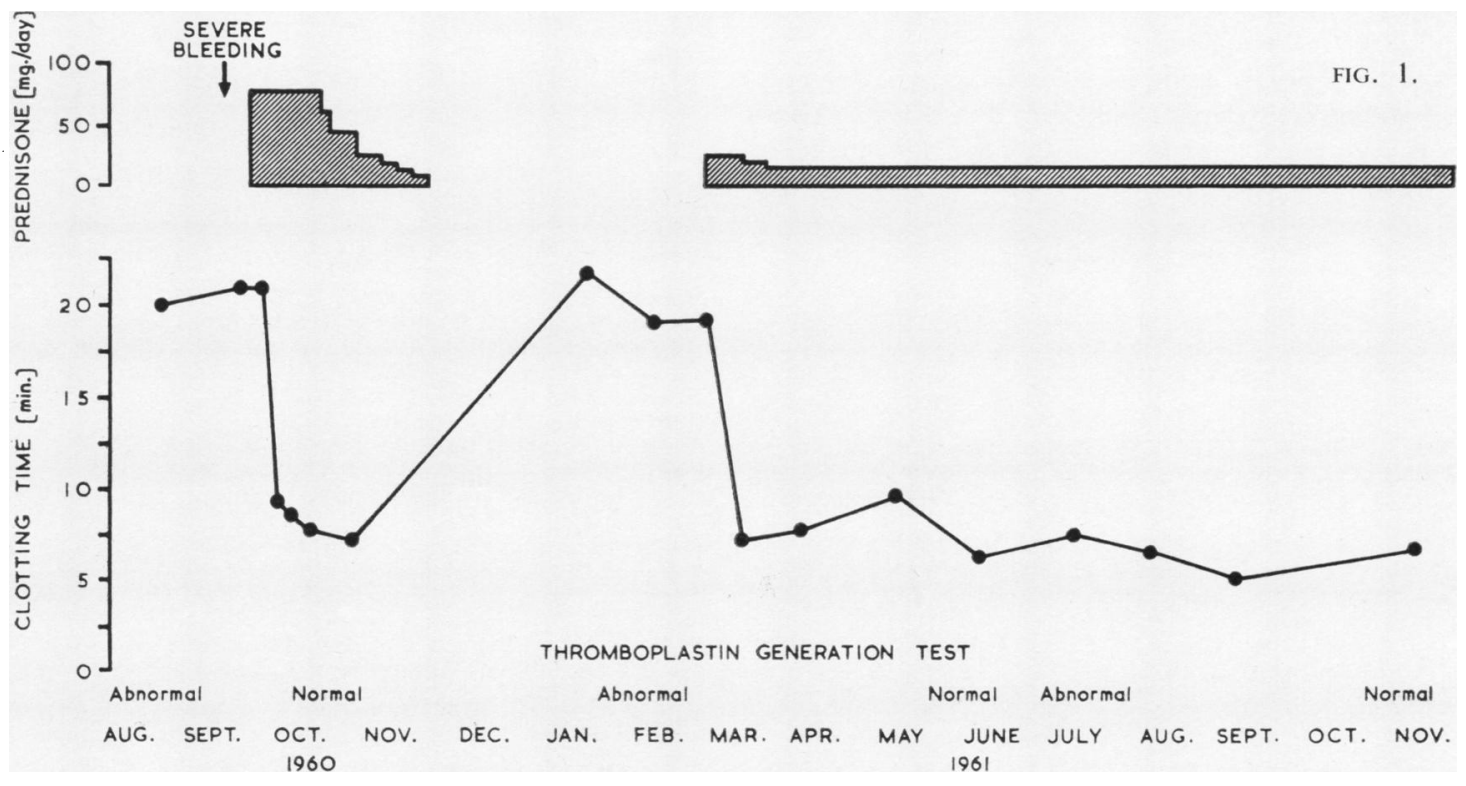

time was 22 minutes and the thromboplastin generation test showed that the circulating anticoagulant had reappeared in the plasma. During the next six weeks the patient had no symptoms but the clotting time was persistently raised and the thromboplastin generation test continued to show the presence of the circulating anticoagulant, so on 28 February 1961 prednisone was again given in a dose of $30 \mathrm{mg}$. daily, and two weeks later the clotting time had fallen to 7 minutes but the thromboplastin generation test was still abnormal. Since then a dose of $20 \mathrm{mg}$. of prednisone daily has been given and has sufficed to maintain a normal clotting time and prevent haemorrhagic manifestations but the thromboplastin generation test still shows the intermittent presence of the circulating anticoagulant.

\section{COMMENT}

Arterial biopsy was not carried out as the diagnosis of temporal arteritis was considered to be beyond doubt. Although the condition is self limiting and the phase of overt cranial arteritis usually persists for only a period of weeks, the disease process often remains active for several years (Cooke, Cloake, Govan, and Colbeck, 1946; Harrison, 1948; Ross Russell, 1959; Paulley and Hughes, 1960). The best guide to persistent activity is the sedimentation rate. The fact that this is still raised in the case described here suggests that giant cell arteritis may still be present in an active form despite the fact that there have been no symptoms for over four years. The development of the circulating anticoagulant may well have been unrelated to the giant-celled arteritis but it seems possible that the processes were in some way connected, though how it is impossible to say. The slightly prolonged prothrombin time suggests that the circulating anticoagulant may have acted more widely than as a pure antihaemophilic globulin inhibitor but all other estimations of the prothrombin time were normal and its main action was undoubtedly at the first stage of clotting.

Response to steroid therapy in reported cases of circulating anticoagulants has been variable. The best results have been seen in cases of systemic lupus erythematosus in which the circulating anticoagulant has disappeared (Medal and Lisker, 1959), or the clotting time has been reduced (Conley and Hartmann, 1952; Bonnin, Cohen, and Hicks, 1956). Patients with heparin-like anticoagulants have also shown a diminution in clotting time (Quick and Hussey, 1957). Circulating anticoagulants interfering with the formation of thromboplastin have usually been unaffected by steroids. Those occurring in much transfused haemophiliacs have been unresponsive (Singer et al., 1950) or the patients have shown some diminution in clotting time (Van Creveld et al., 1953); those developing after pregnancy have been unaffected (Frick, 1953); and those seen in otherwise healthy individuals (Hougie, 1953; Verstraete and Vandenbroucke, 1956) and in association with other diseases (Collins and Ferriman, 1952; Douglas, 1958) have not altered. The case here reported is therefore unique in that a circulating anticoagulant interfering with the formation of thromboplastin by inhibiting anti- 
haemophilic globulin disappeared rapidly under the influence of prednisone, but the effect appears to have been purely suppressive as the circulating anticoagulant reappeared when steroids were withdrawn and permanent maintenance therapy appears to be required.

\section{REFERENCES}

André, R., Dreyfus, B., Jacob, S., and Ley, G. (1952). Rev. Hémat., 7, 296.

Bell, W. N. (1951). Blood, 6, 1199.

Bernard, J., Inceman, S., Zara, M., and Christol, D. (1952), Rev. Hémat., 7, 264.

Biggs, R., and Bidwell, E. (1959). Brit. J. Haemat., 5, 379.

Bonnin, J. A., Cohen, A. K., and Hicks, N. D. (1956). Ibid., 2, 168.

Cetengil, A. I., Ulutin, O. N., and Karaca, M. (1959). Brit. med. J., 2, 38 .

Collins, I. S., and Ferriman, D. G. (1952). Lancet, 2, 712.

Conley, C. L., and Hartmann, R. C. (1952). J. clin. In est., 31, 621 Rathbun, H. K., Morse, W. I., and Robinson, J. E. (1948). Bull. Johns Hopk. Hosp., 83, 288.

-, Ratnoff, O. D., Ellicott, C. E., and Hartmann, R. C. (1950). J. clin. Invest., 29, 1182.

Cooke, W. T., Cloake, P. C. P., Govan, A. D. T., and Colebeck, J. C. (1946). Quart. J. Med., n.s. 15, 47

Craddock, C. G., and Lawrence, J. S. (1947). Blood, 2, 505.

Dieter, D. G., Spooner, M., and Pohle, F. J. (1949). Ibid., 4, 120.

Douglas, A. S. (1958). Brit. J. Haemat., 4, 302.

Fantl, P., and Nance, M. H. (1946). Med. J. Aust., 2, 125.

Frick, P. G. (1953). Blood, 8, 598.

- (1955). Ibid., 10, 691 .
Hardisty, R. M. (1954). J. clin. Path., 7, 26.

Harrison, C. V. (1948). Ibid., 1, 197.

Hougie, C. (1953). J. clin. Path., 6, 30.

Lamy, M., Burstein, M., and Soulier, J. P. (1946). Rev. Hémat., 1 , 421.

Lee, S. L., Sanders, M., and Kahny, H. M. (1955). J. clin. Invest., 34P 1814

Lozner, E. L., Jolliffe, L. S., and Taylor, F. H. L. (1940). Amer. JO med. Sci., 199, 318.

Medal, L. S., and Lisker, R. (1959). Brit. J. Haemat., 5, 284.

Mueller, J. F., Ratnoff, O., and Heinle, R. W. (1951). J. Lab. clin. Med., 38, 254.

Munro, F. L. (1946). J. clin. Invest., 25, 422.

- and Munro, M. P. (1946). Ibid., 25, 814

Nour-Eldin, F., and Wilkinson, J. F. (1958a). Brit. J. Haemat., 4, 38 - - (1958b). Ibid., 4, 292.

Nussey, A. M., and Dawson, D. W. (1957). Brit med. J., 2, 1077 O'Brien, J. R. (1953). J. clin. Path., 6, 326.

Paulley, J. W., and Hughes, J. P. (1960). Brit. med. J., 2, 1562.

Pons, E. R., and de Torregrosa, M. V. (1952). Blood, 7, 20.

Quick, A. J., and Stefanini, M. (1948). Proc. Soc. exp. Biol., N.Y. $\vec{G}$ 67,111 .

- and Hussey, C. V. (1957). Amer. J. med. Sci., 234, 251.

Russell, R. W. Ross (1959). Quart. J. Med., n.s. 28, 471.

Singer, K., Mond, E., Hyman, J., and Levy, R. C. (1950). Blood, 5, 1135 .

Soulier, J. P., and Burstein, M. (1948). Ibid., 3, 1188.

Speer, R. J., Hill, J. M., Maloney, M., and Roberts, A. (1955) J. Lab. clin. Med., 45, 730.

Tzanck, A., Soulier, J. P., and Blatrix, C. (1949). Rev. Hémat., 502.

Van Creveld, S., Hoorweg, P. G., and Paulssen, M. M. P. (1951) Blood, 6, 233.

,,--- (1953). Ibid., 8, 125.

Verstraete, M., and Vandenbroucke, J. (1956). J. Lab. clin. Med., 48 673. 